\title{
Speaking about building Rylands (1960s to 1980s): a Cape Flats history
}

\author{
Uma Dhupelia-Mesthrie
}

\begin{abstract}
This article draws on oral histories of Rylands, a former Indian group area on the Cape Flats. It shifts focus from narratives of dispossession to narratives of the making of a relocation site. The Cape Flats has generally been represented as a place of poverty, crime and hopelessness and existing on the "fringe" of the city. This article seeks to complicate our understandings and imaginings of the Cape Flats by focusing on Rylands. In its focus on the middle class, it argues that they transformed their physical surroundings. Spaces in Rylands, built by Indian capital, also offered the Cape Flats useful resources. As an apartheid-designated space, Rylands had a significant role in the entrenching of Indianness leading to energised cultural and religious activity with temples and mosques becoming the centre for residents. There were competing visions for Rylands; some dallied with apartheid governance structures but, by the 1980 s, the non-racial ethos dominated and for youth this place became their centre.
\end{abstract}

\section{Introduction}

The Cape Flats is an extensive area east of the Southern Suburbs railway line (more particularly, east of the Cape Flats line) and south of the Northern Suburbs railway line (Field 2001, 25). Within it is located Rylands, a former group area proclaimed for Indians in 1957 (Figure 1). Pre-group areas, the Cape Flats represented a frontier zone where, amidst much undeveloped land, people of all races were scattered. Yet, segregated housing schemes for coloureds on the Cape Flats like those in Kewtown, Silvertown and Bokmakierie predated group areas (Le Grange 1985), as did Langa, a township for Africans. It was the implementation of the Group Areas Act of 1950 (Union of South Africa 1950) with its segregated spaces for Indians, coloureds and whites that cemented the Cape Flats as a destination for dispossessed blacks. ${ }^{1}$

In the immediate environs of Rylands lie the former coloured areas such as Belgravia Estate, Silvertown, Kewtown, Bridgetown, Surrey Estate, Vanguard Estate, Crawford and Penlyn Estate (Figure 2). Klipfontein Road separates Rylands from Bridgetown and Silvertown. Johnstone Road (west of Rylands) demarcates its boundary from a light industrial area and Crawford, while a sportsfield and Vygieskraal Stadium further separate Rylands from Belgravia. Eastwards, Vanguard Drive separates Rylands from Surrey Estate 
while on the southern side, Athlone Industria and Turfhall Road separate Rylands from other coloured areas. These buffer zones, a hallmark of group areas, are not as distinctive as the golf courses, wide freeways and parks that separated white group areas from coloured and African areas in Cape Town.

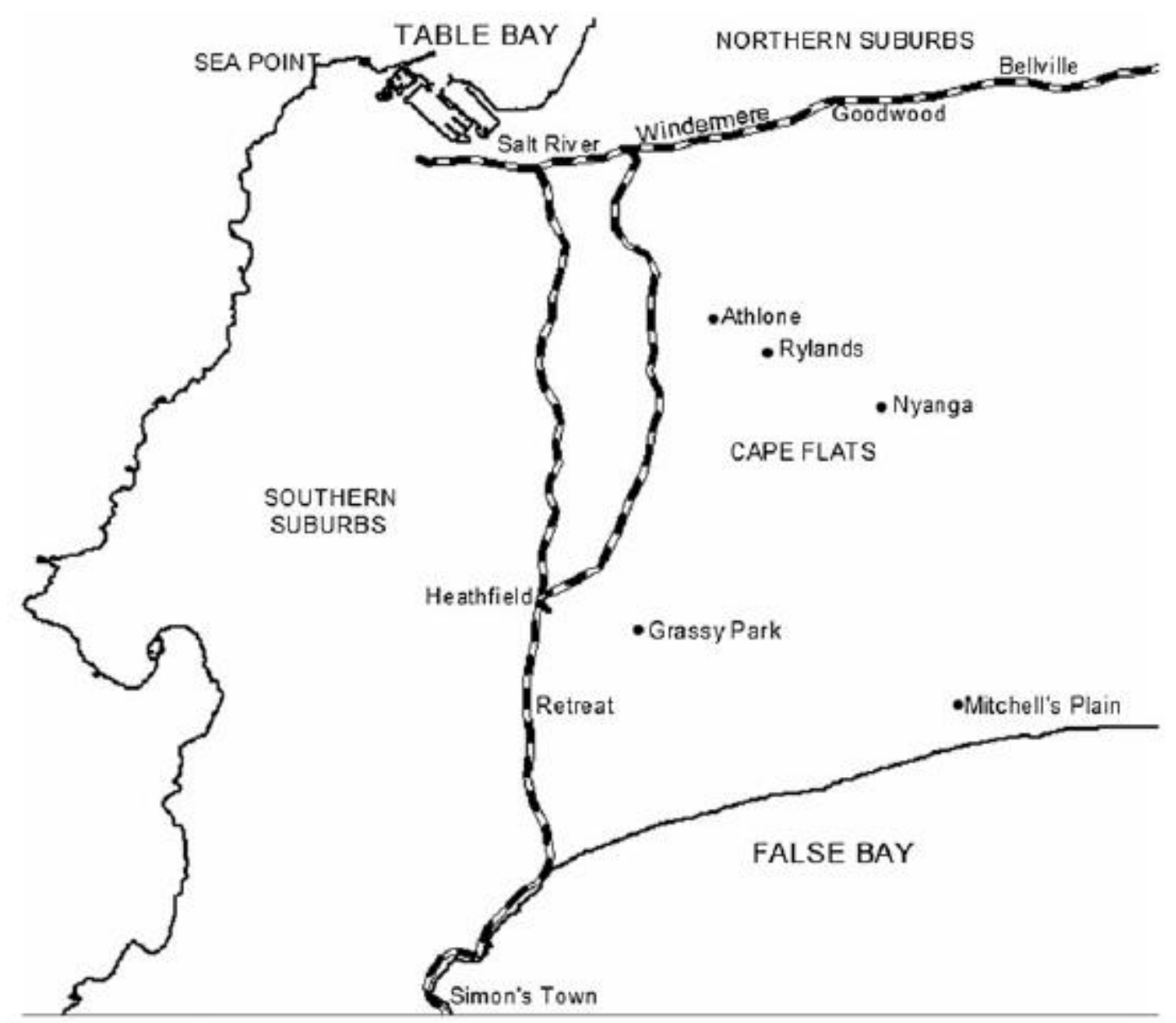

Figure 1. The Cape Flats. Drawn by David Frenchman, Geography Department, University of the Western Cape. Adapted from Field (2001, 25).

From Rylands, one transits seamlessly into Surrey Estate, Crawford and Penlyn Estate. Sandwiched as it is in a wider belt of coloured townships, Rylands is almost invisible in the landscape - blink on Klipfontein Road and one may pass it all too quickly. One description of Klipfontein Road completely ignores the presence of Rylands (Field 2012, 120-121). This is not surprising as it is just $1 \mathrm{~km}$ by $1.5 \mathrm{~km}$ in area (Herald, March 14, 1981). Yet, the Gatesville business section of Rylands is well-known to Cape Flats residents. ${ }^{2}$

The Cape Flats has acquired a particular dominating imagery in Cape Town's history. In the early eighteenth century, it was described by a visiting ship captain as "the large plain that lies to the eastward of the town, which is entirely white sand, like that commonly found on beaches, and produces only small plants of various sorts" (Western 1981, 243). 
The imagery of a windswept, sandy terrain within which only hardy plants survive has endured. With the mass removals that occurred mainly between the 1950 s and 1980 s as the apartheid city took shape, the dispossessed had little affection for this place of resettlement with poor roads and little infrastructure. There are common patterns in narratives of dispossession: the old neighbourhoods from which individuals were evicted are seen as places of community and places of belonging and safety where extended families and neighbours shared meagre resources and took care of each other.

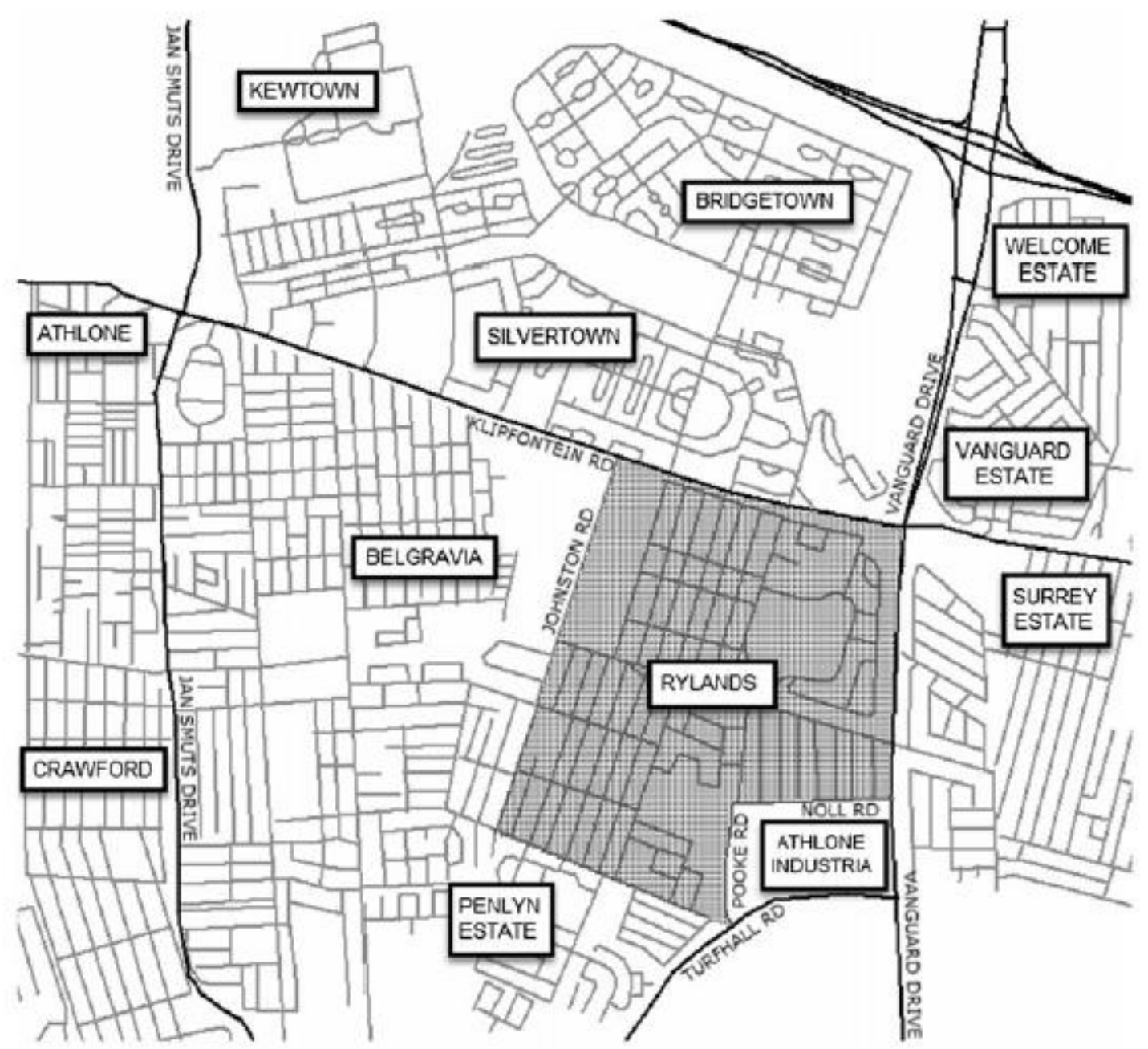

Figure 2. Rylands and surroundings. Drawn by David Frenchman, Geography Department, University of the Western Cape. Adapted from FUNDISA DISC, 2009, satellite applications centre.

The Cape Flats, in contrast, features as a place of crime and lacking community. This was "the bush" and it was "far from the main" (Western 1981; Dhupelia-Mesthrie 2000; Field 2001). Rashied Staggie, a former member of the Hard Livings gang, referred to the new townships that arose as "concentration camps" (Lurie 2004, 120). Lurie titled his photographic tribute to Manenberg Cape Town's Fringe, which Jeppie argues "gives us a 
sense of being part of the whole but not its centre, neither physically nor culturally" (Jeppie 2004, 12).

The Cape Flats is often contrasted with the city beautiful. In the words of the late journalist, John Matshikiza, we have the "the conflicting worlds of Cape Town." There is "the open sea, with paradise - the playground of lush, white houses, the business district and the Waterfront" and the townships which "huddle sullenly behind the mountain's back" (Mail \& Guardian, August 28-September 3, 1998). Steve Robins also contrasts white suburbia and "spectacles of consumption" such as the Waterfront and city malls with the "poverty, wastelands and desolation of the racially segregated black townships of the Cape Flats." In this reading, the poor are "trapped in dangerous spaces" and are "unable to shape their environment” (Robins 2000, 412, 413).

Chris Ledechowski's images in Cape Flats Details (2003) signal another reading as he taps into the creativity of residents and the meanings they have made. This article seeks to further complicate imaginings of the Cape Flats. Urban historians of South Africa have, in Mbembe's and Nuttall's analysis, been overly focused on poverty and struggle with a neglect of "cartographies of affluence" (2004; Mbembe 2004). In its focus on Rylands, where residents possessed greater affluence than the neighbouring coloured population, the article argues that people did change their environment and with some success made it their "main" and their "centre." It was not wealth only that achieved this; the politics of the 1980 s also made places on the Cape Flats "the main." As a racialised space, Rylands, as do other such spaces, offers an opportunity, as Chari argues, to investigate "how [...] people handle racialization" (2006, 105-106, 117). The article argues that Rylands played a significant role in the creation of Indianness and led to a surge in religious and cultural activity. Yet, there was also a competing vision of non-racialism. It is in narratives of the building of Rylands, both its physical landscape and its ethos, that we see these competing visions.

Over a period of years, I conducted 78 interviews with Indians who live in Rylands or have an association of sorts with it. A handful were done in 1995 and in 2007 but by far the bulk of interviews were conducted between 2009 and 2010. I also drew on two interviews with Africans who lived in Rylands done separately by Rajend Mesthrie and Sinethemba Bizela. Interviews took the form of life histories and were dictated by the flow of the conversation, but there were questions about moving to Rylands and activities within it. Most interviewees were male with just 27 being female; effort was needed to secure female interviews. Eight individuals were born in the 1920s, 20 in the 1930s, 24 in the 1940s, 13 in the 1950 s, 10 in the 1960 s and one, the youngest interviewee, was born in 1972. The vast majority were adults born elsewhere in Cape Town before their relocation to Rylands, though a few were children at the time of the move. The interviewees included Hindus, Muslims and Christians and affluent businessmen, factory owners, smaller entrepreneurs, hawkers, dressmakers, those in the catering trade, priests, professionals (doctors, teachers, a mechanical engineer, lawyers and newspaper editors) and housewives. 


\section{Early Rylands}

In the Southern Suburbs and the city centre as the Group Areas Act made its presence felt, the dispossessed Indians, Africans, coloureds and Malays made way for whites and were erased from geographical spaces. In Rylands, the story was different - Indians displaced Africans, coloureds, Malays and a few whites. Early descriptions of this area point to a few shops on Klipfontein Road with bushes, scattered homes behind and much undeveloped land. People kept goats, sheep and chickens (Herald, March 14, 1981). Kholekile Nkewu (b.1946) lived in a shack with his parents in Doornhoogte as the area was known in the 1940 and 1950s. He attended school in a hall that the Xhosas called kwaSukwini. ${ }^{3}$ What he loved most about Rylands was the Royal cinema in Murton Road. He remembers many coloureds living in shacks while Muslims tended to have brick homes. There were very few Indians. ${ }^{4}$ Nkweu says "We befriended anyone from coloureds to Muslims because everyone could speak Afrikaans. We only spoke Xhosa amongst ourselves as Africans" (personal communication, November 2, 2012 - interview conducted by Sinethemba Bizela).

Maulana Qutboodien Kagee's family was one of the few Muslim Indian families in Doornhoogte. Born here in 1940, his family elders were responsible for the founding of the first mosque on the Cape Flats in 1905, the Habibia Soofie Masjid. His father, Imam Abdul Karriem Kagee was the trustee of the mosque and the complex that included a madrassa and orphanage (Habibia Soofie Masjid Centenary Magazine 2005). Locals like Nkewu called the place the "College." Maulana Qutboodien remembers the Doornhoogte of his childhood as sparsely populated with mostly Malays and a few Indian shops (personal communication, January 27, 2010).

Houses were far apart. There was a lot of bushes around. In fact, there was an African location [shanties] here [...] Everybody lived in peace. In fact we would go through the dark hours of the night to the cemetery where Pooke Road is now. At the time there was no Pooke Road. It was a bush area and we would go and bury somebody there or, alternatively, sometimes cut the bushes down in the day to bring wood.

He went to India in 1958 and on his return in 1963, there were "new faces" and the people he had grown up with were gone.

Shamsu Kagee's grandfather, Hajee Ebrahim (Balu) Parker, owned Excelsior Farm on Johnstone Road. In 1943, he purchased additional land in Johnstone Road and was the driving force behind the establishment in 1946 of the Habibia Koknie Educational Institute, later renamed the Habibia Primary School (personal communication, Shamsu Kagee, February 17, 2010; Habibia Primary School 1946-1996 1996). It was the presence of the Habibia Masjid and Habibia School - plus the undeveloped land - which played a role in the allocation of Rylands to Indians. While the Habibia mosque was founded by Indian Kokni Muslims, 5 Malays also attended, and the Habibia School served all races. Emanuel Mandla Thijolo, who was born in 1940 in Forbes Road behind the mosque and school, 
tells his Indian interviewer (Rajend Mesthrie) - his area was "mix" - "I grow up with people like you" (personal communication, 1991).

As it turned out Hajee Ebrahim's dairy farm fell outside the Rylands group area. It was declared as a light industrial area so he sold the subdivided farm to Indians who established businesses - Hadje Ebrahim Crescent commemorates his early presence. A white farmer, Mr. Rix, owned an extensive farm from College Road towards Repulse Road. Ebrahim Omar, then a hawker in District Six, used to come to the area in his horse cart to fetch vegetables (personal communication, November 29, 2007). Kanti Patel recalls that Rix's farm was very productive - there were wells and a big dam - and the soil was fertile, "pitch black." Rix had to relocate to Phillipi (personal communication, January 13, 2010).

At the time of the Group Areas Act, Indians numbered about 8000 in the Cape Peninsula (Scott 1955; Cape Times, March 3, 1953). They were not the homogenous group implied by the state's categorisation. They were of diverse language groups - Gujarati, Konkani and Tamil - and they were Hindu, Muslim and Christian. An identity as Indians, while not absent, was by no means strong and there were no Indian-only schools (DhupeliaMesthrie 2013). Interviewees originated from Claremont, Rondebosch, Observatory, Salt River, Woodstock, District Six, Wynberg, Bellville, Goodwood, Crawford, Belgravia and Athlone. These neighbourhoods had a significant role in the making of their personhood and are often stressed more than their Indianness.

The common refrain about their arrival in Rylands is: "it was bush... bush bush" (personal communication, C. V. Nair, November 10, 2009). There, "little farm paths," not roads (personal communication, E. Omar, November 29, 2007). Johnstone and Repulse Roads were the only tarred roads, with College Road partly tarred. People walked on gravel and rubble as roads and homes were constructed. The dispossessed did not have the same warm feelings expressed by Maulana Qutboodien who grew up here. Dullah Omar, a newly qualified lawyer, brought his bride, Farieda, to a tiny rented home on Johnstone Road in 1962. She says: "Everything was very barren and raw." When they moved into a new house in Mabel Road two years later they endured the bucket system for several years. "You can't explain how it was with the stench," with the buckets cleaned once a week or once in two weeks. Farieda breaks down while relating this (personal communication, November 19, 2007). Several interviewees pointed to isolated homes and no neighbours in the early years (personal communication, S. Naidoo, November 26, 2007; B. Govan, January 16, 2010; F. Allie, December 21, 2009).

\section{Building homes}

In places like Bonteheuwel, Hanover Park, and Heideveld, the city council took responsibility for vast housing schemes and the Department of Community Development (DCD) took 20\% of these units to house the dispossessed ([Dhupelia-]Mesthrie 1994, 74). In Rylands, the city council was a small player in the housing market. In 1979, it owned 22.4\% of housing sites; had developed 215 units in Extension 3 but 209 sites in Extension 5 lay undeveloped. The DCD bought houses from dispossessed coloureds and Malays and resold 
these to Indians. In 1979, it owned 221 sites (11.7\%), 186 of which it had already developed. A series of blocks of flats had been developed in the Gatesville area. In addition, 62 business premises had been built in Gatesville by 1977 with smaller shops within Rylands Estate (Hill 1980, 63-68).

The vast amount of land in Rylands in 1979 lay in private hands (66\%), and one individual Chiba Jeram Patel owned 7.9\% of this. Patel owned 34 sites in Extension 2 and 115 in Extension 4 (none of the latter had been developed, with only six in Extension 2 developed). He also put up a block of flats in Jane Avenue. There were also a significant number of Indians who owned four to five properties each. In 1979, 13,000 Indians were already living in Rylands with 3500 yet to find accommodation (Hill 1980, 63-65).

The oral narratives of securing homes in Rylands are shot through with class differences for those who came here were of diverse socio-economic backgrounds. There are narratives of the less-well-to-do who battled to secure a council home with the city council offering little. Narratives point to preferential treatment of the rich by the DCD with allegations of bribery. At the Community Development Centre pegs on maps indicated which sites were taken and available land was pointed out to people. Houses promised by the DCD on one day would suddenly not be available the next day. Certain people developed closer relationships with officials and managed to secure reasonably priced sites. There are stories of Indians unhappily taking possession of coloured homes, unhappily because the former had lost their beloved homes and the homes on offer were not new. Little thought was spared for the wounded, departing, coloured owners. There are tales of overcrowding with asmany as 15 occupants in a house and difficulties of securing a bond. Those who left moving to the late 1970 s found that land was expensive and scarce. Those who rented often moved several times. Yet, there were professionals and shop owners with means who built their own homes. Some became major landowners. The middle class, which was the dominant group, began to shape Rylands in a significant way.

Dullah Omar managed to build his home because, in repayment for legal services to the Wynberg Muslim community, his house was built at no charge (personal communication, April 25, 1997). Manu Dala, a former Claremont resident and pharmacist, moved to Mavis Road in Rylands in 1972 with his new bride Jasu. He took a keen interest:

It meant a lot because it was a new house I had built. I myself designed it and I had the facilities that I liked [...] I drew a plan and designed the house myself from A to Z. I went to an architect and just put it on paper for having it passed. (personal communication, January 9, 2010)

By the time the house was completed, they were able to get water and flushing toilets. Jamnadas Chauhan, who had lived in Claremont and ran a lawn-mowing business, secured a large plot of land for his house -7500 sq. feet. As an orchid enthusiast he planted over a thousand orchids (personal communication, October 30, 2007). 
Bhagatsingh Govan, an accountant from the Bo-Kaap, soon became a building contractor.

I had to build this house because we had to move from town [...] The architect drew the plans but the quotations I got was [sic] very high. I couldn't afford it. So I had a friend that used to come to the shop and he says 'Why don't you do this ... as owner builder?' I said: 'I don't know anything about construction about building,' but he says: 'We'll help you to get it done.' And that's how I left [...] accounting [...] After I finished building this house I got hooked [...] in building. This is the thing I would like to do. And slowly I've learnt the trade. I didn't know how to mix the dugga - you know the sand and cement ratio - but if you like the thing and you take interest you learn. And I've learnt everything - how the bricks are to be laid - I can tell the brick-layer you doing it wrong or I prefer it this way. (personal communication, January 16, 2010)

Bhagatsingh's new career was long lasting and his knowledge proved useful in other community projects in Rylands.

Bhadra and Gunwant Jaga also developed housing sites (personal communication, April 17, 2010). They together with their father, Kassen, ran a shoe shop in the Bo-Kaap above which they resided. Soon after Rylands was declared, Kassen bought property on Klipfontein Road from the businessman, A.K. Brey, who also owned several other properties in Rylands. Gunwant recalls: "How many objections we had from our Indian community members too. When dad bought it they said, 'Don't buy because you supporting the group area affairs." It is true that in the 1950s and 1960s few Indians were interested in purchasing in Rylands. Many areas had yet to be declared in Cape Town - the big declarations affecting the Southern Suburbs came only in 1961 and District Six in 1966. In addition, the declaration of Rylands was challenged in the courts in 1963 by Abdul Cader Harnekar whose case rested on the fact that the Group Areas Board had not paid significant attention to the numbers of Indians who would be disqualified in proclaimed areas and the sites available for resettlement. He lost the case in 1966 (Western Cape Archives Depot). While many delayed their move to Rylands, early birds established a commanding position.

Bhadra, who married in 1961, lived in the Klipfontein Road house while Gunwant, who married in 1965, moved into his newly built home on College Road in 1975. While they travelled to the Bo-Kaap to run their shop, the house, Gunwant says, offered a new "comfort zone ... [a] very brand-new comfortable house, double storey, six toilets, six bathrooms" [he laughs]. This was a far cry from when three families lived in one home in Wale Street.

Gunwant's father attended auctions and bought properties in Rylands. In 1961, he built semi-detached houses at a cost of R5000 to R6000 each for which he charged a monthly rental of R30 to R40. By 1979, they sold off these homes. They also bought 18,000 sq. feet of land in the nearby industrial complex, Athlone Industria, and built six factories leasing these to manufacturers of lollipops, clothing and spices; one was a printing press. These too have since been sold. There is a sense of pioneering adventure in the narrative of 
the brothers who highlight their father's acute business acumen and foresight in seeing how Rylands would develop. There is also a tale of creativity and craft; Gunwant found it one step away from being a shoe-repairer to getting involved in woodwork and housing. He points out: "We used to build fences to separate the semi-detached houses and to work on a Sunday morning - mix the dugga - for the builders there. It was fun [...] and that's how we developed."

As the son of the largest private property-holder in Rylands, Kanti Patel tells a family story of progress. His immigrant grandfather, a fish hawker at the docks, opened a fruit and vegetable shop in Athlone in 1940 after his grandmother and 14-year-old father, Chiba Jeram, arrived from India. Chiba managed the business, which became known for its bananas. By the time he was 25, Chiba built the Kismet, a "luxury" cinema in Athlone, with 1323 seats. Chiba bought extensive land in College Road in Rylands in 1962 and two years later he and his family relocated from Rylands to the large house he had built. That year he bought a second extensive piece of land. Both purchases were from Mr. Rix, the white farmer, whom Chiba used to meet in the market. Chiba established a construction company - called Bodali after his village in India - and sought to develop a township on the second property. The roads in this area are named after family members.

It took time to build the houses. Six houses were built in Bodali Avenue and the first house was sold in 1981 for R35,000. Chiba then worked to develop the land around the house on the College Road front, opening a Shell garage and a Datsun car franchise in 1976. Cine 400 was opened in 1977 and Club Galaxy in 1978. Behind the cinema complex, a block of flats was completed. Chiba, who went on a world tour in 1968, studied building designs and created spacious flats with four to five bedrooms suitable for large families.

Kanti marvels at his father's enterprising spirit, a man who only had a standard five education. His father was a hard taskmaster. He would sit his errant children down and lecture: "What it's all about? Its blood, sweat and tears. That's his famous line. You do anything wrong [and] he'll remind you where he came from and how hard he worked." Club Galaxy was initially to be a "five-star restaurant," "a fancy upmarket restaurant." Within a month the restaurant gave way to a disco for 1978 was the year that Saturday Night Fever starring John Travolta was released and the dance craze began. "It was a very, very successful business from the day we opened up." Kanti managed Club Galaxy and the later West End fusion club. Indian Rylands hosted musicians, music lovers and dance enthusiasts from across the Cape Flats and the venues became known for jazz performances.

Kanti tempers this narrative of accumulation by pointing out that Chiba also provided bread for the large number of squatters between Cissie Gool Road and Vanguard Drive whose informal settlement was called "The Damage." He installed a tap for free access to water. "It was quite a thing here on Thursdays, people queuing here early morning already just to get bread." Chiba, as we will see, also donated land for the construction of a temple in Rylands. 
The bigger homes came to dominate the landscape of Rylands and in the 1970s The Herald, a newspaper that reported on the activities of coloured people on the Flats, produced a series of articles highlighting "the monotonous jungles of cheaply built municipal flats and dwellings" of the Cape Flats and this new "gem of the Cape Flats." Articles provided descriptions of lush interiors and pools (Herald, July 28, 1973; June 28, 1975; April 10, 1977; July 28, 1977). In the 1980s, it drew attention to diversity within Rylands of "sumptuous - almost palatial homes" and the more "ordinary three-roomed homes [...] council flats [...] [and] wood-and-iron houses" (Herald, March 14, 1981; October 27, 1983).

The above narratives point to how Rylands presented new opportunities for some, how there was some enthusiasm and how new skills emerged. The "bush" gave way to orchids and homes and businesses. Words like "fun" and "comfort zone" generally not associated with life on the Cape Flats are used. Organisations emerged in Rylands and these worked with the local management committee (mancom) and the South African Indian Council (SAIC, founded in 1964), a national body" both created by the state to take care of representing Indian interests. The Rylands Civic Association (RCA, founded in 1966) fought for a "dry Rylands" by opposing liquor outlets and worked with SAIC to improve conditions. Gopi Mansook, a secretary of the catering trade union, was a member of the RCA and the SAIC (Cape Times, February 27, 1971; November 29, 1972). The RCA successfully contested the first elections to the five-person mancom in Rylands in 1974 (Cape Times, June 27, 1974). The Reverend Edward Manikkam stood as an independent in 1976 (Cape Times, June 18, 1976). Mancom tried unsuccessfully to get municipal funds allocated for a swimming pool, hall and library (Cape Argus, August 6, 1975).

There is little doubt that mancom was important for those seeking to advance business interests. Chiba Jeram stood for elections, though he was unsuccessful (Cape Times, June 27, 1974). Mancom members like Manikkam, Gang Naidoo and Mansook also saw themselves as advancing the interests of the poorer sections in Rylands. Gang argues that one had "to get into mancom because if the wrong people got on there they sell our people. It's been happening all along." This reflected a divide between the better-off Muslims (who were represented on mancom) and Tamils who were mainly in the catering trade. Gang has no regrets being a mancom representative, for he feels he did much to help the poor with housing issues (personal communication, January 8, 2010).

Kista Reddy, a barman, successfully secured a home in the elite Shaanti Crescent from the DCD with Mansook's help. He speaks of Mansook's role in bringing change to Rylands:

That time it was very, you know, the roads was not very good. I think Mansook had to bring the mayor around and drive through the road. They called it a developed area but he said you don't call this a developed area with the road with big potholes. So [they] did the roads up and now we have got beautiful roads. (personal communication, January 8 , 2010) 
Many interviewees said they knew little about mancom elections, or what its members did. At the first elections only 500 of an estimated 4000 to 5000 registered to vote (Cape Times, March 12, 1974). In 1982 just over 150 voters cast their vote (Cape Times, June 16, 1982).

Another body, the Rylands Indian Welfare Association, chaired by Reverend Manikkam, was reported in 1970 to have had asked the Department of Indian Education to have schools built in Rylands. Members of the RCA were divided on the issue given the fact Indians had always attended coloured schools. Manikkam and C.C. Palsania used their position as SAIC members to argue that Indian pupils had to seek admission to coloured schools, where preference was given to coloured children. Their efforts bore fruit in June 1976 when Rylands Indian High School, the first Indian school in Cape Town, opened. This was one of the most controversial buildings in Rylands and activated substantial opposition. The community was so hostile that the school was forced to drop the Indian tag (Cape Argus, May 20, 1970; Cape Times, March 10, 1972; February 21, 1973; March 18, 1975; Cape Herald, July 20, 1976).

\section{Building religious sites and culture}

Rylands also provided the opportunity for building the first temples in Cape Town for, prior to its establishment, Tamils generally met at each other's homes for services and the Gujaratis gathered at a hall in Mowbray. Mansook, who had hosted services at his Salt River home, relegated a huge room in his newly built house in 1975 in Shaanti Crescent for worshippers of the Divine Life movement, an Arya Samaj reform movement (Herald, June 28, 1975). The Tamil community bought the Apostolic Church in Ruth Road once used by the former coloured residents and used it as a hall. A temple, the Siva Aalayam was built on the adjoining site in 1976, making it the first temple in Cape Town (Siva Aalayam 35th Anniversary Brochure 1999). C.V. Nair, the long-time president of the Siva Aalayam, argues it was the establishment of Rylands that made this happen.

Oral narratives accord women a significant role in the religious activities of Siva Aalayam. Goonam Pillay, the sister of the now well-known playwright and author, Ronnie Govender, lived in Cowrie Street in the city centre before coming to Rylands in the 1960s. In 1966 she was a founder member of the Rylands Hindu Women's Association (RHWA), which assisted families in a time of death, conducted prayer services, promoted Indian culture and raised funds for the construction of the temple. The fundraising committee met at each other's homes. Goonam says: "It was such a fun thing [...] We being a small community we used to be very close and one of us used to say 'Please, don't forget to do that or bring that here. Do the flowers. Do the garlands.' They were so willing [...] They will all sit there all laughing, happy go lucky." They screened Tamil films brought from Durban, held concerts, and hosted a sari queen contest in the Luxurama theatre in Wynberg (personal communication, November 12, 2009).

The DCD offered two religious sites in Gatesville for purchase, one for Hindus and one for Muslims. The temple site led to a major division between the Gujaratis. 
Two warring groups built two temples, one on the DCD site and one on private land donated by Chiba Jeram. The tale of two temples is fraught with angry and anguished narratives. Individuals refused to be named when discussing this, while at least two of those who were involved in the discussions at the time were defensive of their own positions and lashed out quite viciously at the other parties, despite all this having happened in the 1970s. Kanti Patel reflects the sentiments of many of the youth at that time.

The split really caused a lot of hatred amongst the community at that point in time and it was totally uncalled for really. If you look at it [...] there were two parties. They were both quite set in their ways I would say [...] It became a power struggle and instead of using the one [site] just to make a hall out of it and the [other] one a temple - you know, they could have done something and compromised. That split was really one of the sad moments as far as I am concerned as long as I am living here in Rylands.

It was the Gujarati shoemaker caste that precipitated the crisis by securing the DCD site for their caste organisation. ${ }^{6}$ Caste organisations had always existed among Gujaratis yet there was also an umbrella Gujarati body, the United Hindu Association (UHA), later renamed the Cultural Hindu Society (CHS). The Group Areas Act threw the Gujarati community into some turmoil. The Gujarati vernacular school (f. 1947) owned by the UHA in Newlands was expropriated and similarly the hall owned by the shoemaker caste in Mowbray was sold. The latter saw the DCD site as a replacement for their loss. The CHS felt that as the main Gujarati Hindu organisation, it should build the temple and its plans were to build on the land that Chiba made available. This became an epic battle between the shoemakers and the rest of the Gujaratis. Oral histories point to strong personalities on both sides that drove the rift and they miss the insidious role of the Group Areas Act and the DCD with its land offerings.

In 1983, the shoemaker caste completed a hall, the Samaj Centre, with an adjoining temple, the Vishnu Mandir at a cost of R600,00o. Bhanu Jaga, who was on the women's group of the temple, elaborates on their role:

We used to do fundraising. Now the temple came up so the first thing is [...] the men needed funds so we thought we will do rummage sales. [We] went to cake sales. So every Saturday we made groups and we six ladies used to go [...] we went to Retreat. We went to Athlone, put our trestle up there, and made hot bhajia, rotis, curries and we used to sell them, seven o' clock to one o' clock. We did lots of work and we [...] really raised money that time. That kitchen we paid for in the Samaj Centre [...] We gave them quite a bit for the foundation and we ladies did really well and we had a wonderful group. Each one did their share. Each lady, they never said No. Tell them to do 50 rotis they were there for us. [...] Then we did rummage sales - all our old clothes and saris [...] we sold it. They bought it as curtaining - the coloured people really went crazy buying our clothes and our saris. (personal communication, April 17, 2010) 
In this sense, the Cape Flats contributed to the Samaj Centre but the bigger portion of funds came from donations from individuals in the community.

The CHS proceeded with its own project and Bhagatsingh Govan put his newly acquired building talents to oversee the contract work. The first building, completed in 1985, housed the Wonderland Pre-Primary School and the Gujarati school, until this time hosted in a variety of premises, also moved here. The Radha Krishna temple was the final building in the complex. A planned hall has still not been built but there is extensive land for this. Jeram Patel, echoes Nair about the move to Rylands:

"As we all know we got the temple [...] and that was quite a benefit" (personal communication, February 8, 2010).

The acquisition of the mosque site has a less dramatic story. The history of the MasjidulQuds or Gatesville Mosque, which celebrated its 25th anniversary in 2010 has been documented in a glossy coffee table volume. The book notes: "As the communities reluctantly settled down to their enforced lifestyle, issues like education, religion and financial stability became the top priorities." It credits the Muslim League of South Africa, established in the early 1970s, with the inspiration to apply to the DCD for the mosque site since religion was an important "cohesive force" (Parker 2010, 17-18). The DCD required it to prove that its plans had the support of the people and so they conducted a survey. Abdulla Gangraker, a businessman and head of the Wembley Group of Companies and owner of the Cape Flats landmark in Belgravia, the Wembley Roadhouse, financed the purchase. Once the land was secured in 1980, the Gatesville Masjid Educational Institute (f.1983) oversaw the building operations. The foundation stone was laid in 1985 and the mosque, which can hold 3000 worshippers, was officially opened in 1989. It included a library and a madrassa. The book is replete with details and pictures of the work of the architect (Mohammed Allie Harnekar), the work of Moroccan artisans, and the design of the Turkish carpet.

I interviewed Gangraker (a trustee of the mosque), Sataar Parker (once chair of the executive committee of the mosque) and Rauf Khan, a former treasurer. Gangraker related how he was once asked about which of all his many achievements gave him the greatest joy. He pointed me to an artist's impression of the Gatesville mosque in his office.

And it was lying in front of me [...] on my desk and my eyes fell on it. And I said I got an answer [...] My involvement with the Gatesville mosque [...] I acquired blessings, I acquired good friends [...] and that made me a better person. And every day there is something that I do. Phone somebody about the mosque. Today I was enquiring about a brass strip [...] I asked my maintenance man please go and see where it is. [...] All the administration of the mosque is done through my office free of charge. (personal communication, March 29, 2010) 
Khan also signalled the importance of the mosque in his life. He explained to me the details of everyday maintenance and his role in collecting the weekly Friday donations and the annual Ramadaan collection: "I love doing that. I say if I die I can say I served some other cause" (personal communication, December 21, 2009).

Parker, who once worked for a company constructing and selling homes in Mitchells Plain, explains what distinguishes the two mosques in Rylands. He acknowledges the role of the Habibia Mosque as the oldest and points out it is a mosque run primarily by family members. The Gatesville mosque is different in that it promotes "scholarly discourse" (personal communication, November 12, 2009). Other interviewees explain that people go to whichever mosque suits them - some are by family tradition attached to the Habibia Mosque while others are interested in the lectures at the Gatesville mosque, which can be political. Majid Mowzer, who came to Rylands in the 1970s as a young schoolboy from Claremont, prefers going to the mosque in Claremont for Ramadaan but, otherwise, goes to either of the two mosques (personal communication, December 20, 2009). Ebrahim Omar maintains his involvement as a board member with the Zeenatul Islam Masjid (the Muir Street Mosque) in District Six, which was built by Indian Muslims in 1923 (personal communication, November 29, 2007).

The observation of Hill in 1980 that "Christians as such a small minority, are seldom publicly conspicuous" in Rylands, still has relevance (1980, 74). Manikkam, a pastor of the Dutch Reformed Church, secured additional land from the DCD for his church in Mabel Road but it had a small following. Moses Mathews, a teacher from Durban who came to Rylands to teach at the Rylands High School, throws some light on what it means to be a Christian in Rylands: "It means that you will be very, very lonely" to which we both burst into laughter. He and a few other teachers first observed church services in the school but this was not really meaningful. He and his wife tried about 13 churches in various areas before settling on the Baptist Church in Silvertown where he happily fitted in with the congregation (personal communication, December 19, 2009).

While religion led to separate spaces being carved out, other activities brought people together. Rylands Homecraft was started in 1983 and Jasu Dala, a founder member, stresses that "From day one [it was] open to all not just Gujaratis" (personal communication, January 9, 2010). The women met in the Samaj Centre to develop cooking, sewing, knitting and flower-arrangement skills. Another unifying body was the Rylands Cultural Association (RCA, f. 1971). Founder members Sataar Parker, Jamnadas Chauhan and Dada Parker came originally from Woodstock, Claremont and Protea Village in Constantia respectively. They shared a love for Indian music and Rylands provided the space to foster this. Dada Parker explains that the RCA "brought the [...] community together Hindu, Muslim, everybody [...] because of the love for music" (personal communication, July 6, 2009). Sataar explains they started talent shows for the youth that gathered such support that they had to seek big venues such as the Luxurama in Wynberg and the Three Arts Theatre in Plumstead. The proceeds were donated to charity. The RCA produced a play, Reshmi Kafan (The Silken Burial), which was written by local playwright A. Kays. The RCA hosted leading singers from India in the 
1970s such as Mohammed Rafi, Mahendra Kumar and Kishore Kumar (personal communication, November 12, 2009).

Savitri Naidoo reflects on how Dada Parker's living room in Tussen Road became an interactive cultural space for youth as they gathered for rehearsals. Her love for classical Indian dancing, first inspired by the RHWA, was harnessed by the RCA, which raised funds for her to study in India. Savitri emphasises: "Everybody was together. It wasn't you Gujarati, you Hindi, you Tamil, and I'm Muslim. We were always together [...] I felt that if you were a child of Rylands no matter what you did the whole community stood behind you" (personal communication, November 8, 2007). As I have argued elsewhere (DhupeliaMesthrie 2012a, 295-312) in this statement, Savitri upturns the literature that relocation sites were alienating and it points to the need to examine these relocation sites from the point of view of the youth who knew little else. In 1979 she started the Vadhini Indian Dance Academy in Rylands, which also unified Indians as did Abbobaker Ismail's organisation Aphsara Promotions. Ismail's plays reflected the quest for unity amongst Indians - Ram aur Rehman drew on Hindu and Muslim figures and Teen Watan Ek Saath ("Three Countries Together") was about India, Pakistan and South Africa.

While these organisations did much, the reality is that several Indians felt the religious, linguistic and class divides. Neil Nair, a Christian, came to Rylands with his parents in 1979 when he was 10. The son of a barman, he felt divisions keenly.

Here were the Gujarati groups, the Hindu groups, the Muslim groups, the Christian groups [...] and also the class differences that very clearly manifested along the religious lines. You'd find certain kinds of religious groups more affluent [...] and one felt an obvious sense of difference between the different groups. (personal communication, February 4, 2010)

While some organisations brought people of the same religion together and the cultural organisations sought unity across the diverse religious and linguistic groups, there were others in Rylands who were concerned to build bonds across the Cape Flats and to build an ethos of non-racialism.

\section{Crossing borders: building non-racialism}

The above account presents a very narrow picture of Rylands - of people buried in cultural and religious activity or seizing opportunities. Yet, people were not trapped in this narrow space - they left daily to work elsewhere and in the early days young children crossed into coloured areas for schooling. Premesh Lalu, who came to Rylands from Wynberg with his family in 1971 when he was four years old, went to Silver Lea Primary School in Silvertown. He recalls:

There were no schools in Rylands so there were many of us from Rylands that went to Blossom Street Primary School or Silver Lea. And because it was in Silvertown, it meant already that one was transgressing a certain boundary, an apartheid boundary. And 
Klipfontein Road [...] was a boundary that was traversed on a daily basis not only to go to school but all my friends were in Silvertown. And so I spent a lot of time outside of Rylands and I remember the big soccer field when it was created in Johnstone Road, all the kids from Silvertown came to play on that soccer field. So there was a lot more movement. (personal communication, January 28, 2010)

Premesh later went on to Peak View in Bridgetown and Belgravia High School. Peak View was rough and Bridgetown was plagued by gangs but Premesh credits the school as the place where "I unlearnt my Indianness. I gave it up because it had no currency. It was a liability [...] there was you know a class reading of where I came from in Rylands."

There were others who sought to ensure that spaces in Rylands did not become overracialised, as was seen in the opposition to Rylands High School. When the Wonderland Pre-School opened, Kanu Sukha, on behalf of the CHS, was adamant: "If we were to apply for a state subsidy there would be a problem admitting all children - we would be restricted to certain population groups only. We are not prepared to do this as we want the school to be non-racial" (Herald, February 23, 1985). There were also many coloured women who lived in Rylands because of their marriage to Indian men. Savitri Naidoo's mother, Sheila Gangen, and Thelma Rajah were easily welcomed into the Tamil community (personal communication, November 26, 2007 and April 12, 2010). Zainub Kolbee commented on residents of the Gatesville Flats: "It's a pot of biryani right across. We're all a mixture of all kinds here" (personal communication, April 18, 2010).

This is not the place to recall the history of the schools boycotts of the 1970 and 1980 s and the Cape Flats township uprisings. The point that needs making is that Cine 400 and the Samaj Centre, built by Indian capital, came to be widely known across the Cape Flats as both sites were given for meetings and Kanti Patel's generosity is widely acknowledged. Dullah Omar provided the inspiration for a new brand of politics in the area. Activists also mention the influence of Jean Naidoo who had a high profile in the aftermath of the Soweto riots. Premesh recalls:

And I went to a rally at the Cine 400 and I couldn't get in. I remember I tried to squeeze into the cinema. It was packed and there was an overflow downstairs into the nightclub and we all sat there. There was this big screen and Dullah spoke and I remember [...] it was Dullah's talk which appealed to me. Here was someone who spoke in a tone and with a degree of, you know, just measuredness and intelligence that I found really appealing. I was absolutely bowled over. So I went back to school and I joined the COSAS [Congress of South African Students] branch.

In May 1981, Dullah inspired the founding of the Thornhill Residents Association (TRA), a name drawing on the early name of the area (Doornhoogte). The TRA rejected racial and ethnic divisions and sought to "produce a political tradition which will counter all reactionary influences" (Grassroots, June/July 1981). Many of its members were on the parents support committee at the Rylands High School during the 1970s and 1980s. The 
TRA took up rates issues and mobilised people to reject the separate governance structures of apartheid. The RCA, vocal in the 1970s, was relegated to the sidelines. In the 1982 mancom elections there was a poll of $15.6 \%$ compared to 61\% in 1976 (Cape Argus, June 16, $18,1982)$.

Dullah Omar's home in Mabel Road became an important place for the youth. Premesh remembers with a chuckle: "He had a solution to everything, to every problem you created, so whatever trouble you created at school that we couldn't resolve we would go to him we'd say we've done this what do you suggest we do?” On one occasion, Premesh went to the house with two other high school students, Rajesh Bhoola and Peter Williams, a school friend from Kewtown. Dullah impressed on them:

We must maintain democratic practices at school and he insisted that we build a nonracial movement. That we do not build a movement in Athlone alone but that we build a movement with schools in Gugulethu, Langa, Crossroads, Khayelitsha.

Premesh emphasises:

He was non-compromising on building non-racial politics across racial boundaries. So the first rallies we had he would ask us 'Who are you inviting to speak? Which schools from Gugulethu are coming to the rally?' And as a consequence we organised one of the most incredible rallies at Rylands High [...] in which all the schools from the township descended.

Suren Pillay, who went to Rylands High and was encouraged by Saleem Mowzer, a teacher, to join the youth wing of the TRA, provides a sense of Dullah's home:

We used to use his library quite a bit and that was I think the first time I encountered somebody who had a library of books, you know, and that was quite incredible to us. And the house was open to us all the time and we could go and use the library. And then in the youth [organisation] he'd come and speak [...] and in the residents [association] he was more [...] more physically present I think at the time. But as he became more and more active in the UDF [United Democratic Front] [...] the interaction was less [...] But you also had a sense that there were people coming in and out of the house all the time, like UDF executive people and national figures. (personal communication, February 10, 2010)

Neil Nair also recalls:

It was a place of learning where we would get together and talk together about dialectics and Marxism and Leninism and talk about two-stage revolution and fight with each other and argue. And we jammed and we'd organise [...] That's where I learnt project management. Yes, in planning how to distribute pamphlets, how we going to print the pamphlets, how we going to start working with the UDF to build UDF structures. It 
was so amazing. But those skills just don't leave you because somebody asked me once where did you study project management? I wanted to say that's where I studied.

Premesh, while acknowledging the trappings of Rylands as a group area, also comments that it was "a generative space [...] a space that held out possibility. It was anything but a narrow identity formation. It was everything about how one looked outside and beyond and moved across and travelled and learned." Neil Nair felt that there was "an energy" and Rylands was "the centre of what was happening in Cape Town." For Suren Pillay, it was a place "of coming to consciousness." In this sense the idea of "the fringe" recedes.

\section{Conclusion}

The oral narratives reveal the complexities of a space like Rylands. While they point to details of local sites, local people and local happenings they have a broader significance for understanding the diversity of apartheid's relocation sites and the building of life across the decades. Building refers to houses, businesses, religious sites and unity amongst Indians and across the racial divide. The relocation site also caused divisions as competition for the shaping of the landscape surfaced. The prioritisation of narratives of individuals with wealth and skills points to the energy and even enthusiasm with which dispossessed individuals sought to make the best of new circumstances. Rylands challenges the dominant image of the Cape Flats by pointing to the capacity of individuals to change and transform their environment. The article points to how when the wealthy and better off were segregated they turned this to an advantage by appropriating land and building and leasing and creating spaces of warmth, comfort and capital accumulation. The language used is different from that generally associated with stories of dispossession. The idea of the Cape Flats as a "fringe" is complicated here for sites in Rylands became the centre of existence - be they temples, mosques or the homes of individuals like Dada Parker or Dullah Omar. In the 1970 and 1980 s with its resources and its facilities, Rylands afforded a useful space to the rest of the Cape Flats in the struggle against apartheid. In the broad alliances that were forged across the Cape Flats, the competing vision of non-racialism took root. The view from Rylands was not one of being on the edge of things but at the centre.

\section{Acknowledgements}

The author would like to thank interviewees for their time. They all consented to having their names used. The views expressed here reflect that of the author.

\section{Funding}

This research was funded by the National Research Foundation and the Senate Research Committee of the University of the Western Cape.

\section{Notes}

1. I use the term "blacks" in the 1970 s and 1980 s sense of being inclusive of coloured, Indian and African.

2. Rylands has several subsections such as Rylands Estate, Gatesville, Hatton Estate and

3. Doornhoogte. 
4. According to him this was a term referring to Xhosa-speaking coloureds.

5. The Muslims to which he refers to were Malays, a term which from the nineteenth century came to refer to Muslim slaves and ex-slaves of diverse geographic and ethnic origins.

6. The majority of Indian Muslims in Cape Town come from the Konkan belt in what is today Maharashtra, India.

7. Gujarati Hindus were divided into a number of castes and the shoemakers were the largest, followed by the Patels (for a fuller exposition of this see Dhupelia-Mesthrie [2012b]).

\section{Notes on contributor}

Uma Dhupelia-Mesthrie is a senior professor in the Department of History at the University of the Western Cape. She is author/editor of From Cane Fields to Freedom: A Chronicle of Indian South African Life (Kwela Books, 2000); Sita: Memoirs of Sita Gandhi (Local History Museums and South African History on Line, 2003); Gandhi's Prisoner? The Life of Gandhi's Son, Manilal (Kwela Books, 2004). She has written on group areas and land restitution in Cape Town and has a project titled Cape Flats Histories. She intends producing a book on Rylands and is also working on the Cape Town immigration bureaucracy and systems of identification. 


\section{References}

Chari, S. 2006. "Life Histories of Race and Space in the Making of Wentworth and Merebank, South Durban." African Studies 65 (1): 105-129.

Dhupelia-Mesthrie, U. 1994. "The Tramway Removals, 1959-1961." Kronos 21: 61-78. Dhupelia-Mesthrie, U. 2000. "Dispossession and Memory: The Black River Community of Cape Town." Oral History 28 (2): 35-43.

Dhupelia-Mesthrie, U. 2012a. "Cultural Crossings from Africa to India: Select Travel Narratives of Indian South Africans from Durban and Cape Town, 1940s to 1990s." South African Historical Journal 64 (2): 295-312.

Dhupelia-Mesthrie, U. 2012b. "Gujarati Shoemakers in Twentieth-Century Cape Town: Family, Gender, Caste and Community." Journal of Southern African Studies 38 (1): $167-182$.

Dhupelia-Mesthrie, U. 2013. "Cape Indians, Apartheid and Higher Education.” Journal of Natal and Zulu History 31 (1): 45-74.

Field, S., ed. 2001. Lost Communities, Living Memories: Remembering Forced Removals in Cape Town. Cape Town: David Philip.

Field, S. 2012. Oral History, Community, and Displacement: Imagining Memories in Post-Apartheid South Africa. New York: Palgrave MacMillan.

Habibia Primary School 1946-1996. Fiftieth Anniversary Magazine. 1996. Cape Town: Selfpublished.

Habibia Soofie Masjid Centenary Magazine: A Spiritual Legacy of a Hundred Years. 2005. Cape Town: Self-published.

Hill, R. A. 1980. "The Impact of Race Legislation on Kinship and Identity amongst Indian Muslims in Cape Town." MA diss., University of Cape Town.

Jeppie, S. 2004. "Introduction." In Cape Town Fringe: Manenberg is Where It's Happening, edited by D. Lurie, 9-17. Cape Town: Double Storey.

Le Grange, L. 1985. "Working Class Housing, Cape Town 1890-1947: Segregation and Township Formation." Cape Town: Africa Seminar, Centre for African Studies, University of Cape Town.

Ledechowski, C. 2003. Cape Flats Details. Pretoria: SA History Online and Unisa.

Lurie, D. 2004. Cape Town Fringe: Manenberg is Where It's Happening. Cape Town: Double Storey.

Mbembe, A. 2004. "The Aesthetics of Superfluity." Public Culture 16 (3): 373-405. Mbembe, A., and S. Nuttall. 2004. "Writing the World from an African Metropolis." Public Culture 16 (3): 347-372.

Parker, A. S. 2010. The History of Masjidul-Quds: Celebrating 25 Years of Devotion and Inspiration. Cape Town: Masjidul-Quds Institute.

Robins, S. 2000. "City Sites: Multicultural Planning and the Post-Apartheid City." In Senses of Culture: South African Cultural Studies, edited by S. Nuttall and C. Michael, 408-415. Oxford: Oxford University Press.

Scott, P. 1955. "Cape Town: A Multi-Racial City." The Geographical Journal 121: 149-157.

Siva Aalayam 35th Anniversary Brochure. 1999. Cape Town: Self-published.

Union of South Africa. 1950. Group Areas Act, Act 41. Pretoria: Government Printer. Western, J. 1981. Outcast Cape Town. Cape Town: David Philip. 
Western Cape Archives Depot Cape Town, MC Barker Papers A316. Vol. 20. Case of Abdul Cader Harnekar versus the Group Areas Board, 1966. 